\title{
The Operational Indicator of "Insani" Resources Criteria As The Implementation of Islamic Human Resource Management
}

\author{
Ali Arifin ${ }^{1 *}$ and Nurlaili Adkhi Rizfa Faiza ${ }^{2}$ \\ 1,2 Universitas Islam Negeri Sunan Ampel, Surabaya, Indonesia
}

\begin{abstract}
Human being has function as Khalifah fil ard means that has qualification as man power in maximizing the function of organizing resources. In an organization, the khalifah function is to achieve a maximum results acknowledge as Insani Resources (IR). The aims of this writing are to break down the criteria of Insani to be operatively in strengthening the theory of human resource management. This paper focusing on three criteria of Insani Resources; Al-Qawiy Al-Amin (QS: [28]: 26), Makinun Aminun (Surah: [12]: 54) and Hafizun Alimun (Surah: [12]: 55). In sort, the relevance of AlQawiy Al-Amīn, Makinun Amīnun and Hafizun Alìmun, that the criteria of IR Al-Qawiy Al-Amīn, Makīnun Amīnun and Hafizun Alìmun have entered the standard of IR qualification of Islamic economics
\end{abstract}

Keywords: Al-Qawiy Al-Amīn, Hafïzun Alīmun, Insani Resource (IR), Makīnun Aminun

\section{Introduction}

The position of human resources in economic activities is urgent. In some aspect its play significantly in generating multiplier value of economic. Richard Floridas' theory about creative class underlines the position of human resources as the main factors in economic growth. In Islamic prospection, human resources tend to have similar function and use insan kamil or perfect man in explaining human resources. Referring to Yusuf Suit Almasdi in Ardana postulate that explain the position of human resources as the center of thinking, innovating, initiating, and developing nearby resources for the welfare of human life. Therefore the quality of human resources determine the ability in anticipating future demands, having positive attitudes, behaving commendable, and insightful, and also has skills and expertise to suit the needs.

There three basic characteristics of high quality human resources, first has adequate skill and ability in certain tasks both physically and mentally. Second has affordable knowledge through adequate education and experience. The last but not least is having a good attitude and manner in interacting or communicating with fellow human beings.

National Professional Certification Board (Badan Nasional Sertifikasi Profesi BNSP) has three components of adequate human resources. The first component is having technical competence, a competence that related to ability to deal with technical issues. Second component is having spiritual competence. A competence related to discipline, dedication, integrity and loyalty, work ethic, work motivation. The last component is having social competence. A competence in work together, to get along, to communicate, to coordinate, the ability to appreciate the opinions of others and the ability of cooperation in the team.

* Corresponding author. Email address: $\underline{\text { aaarifin07@uinsby.ac.id }}$ 
Ahmad Hawari (2009) have four qualification about man power: Having Intelligent Quotient (IQ), Having Emotional Quotient (EQ), Having Creativity Quotient (CQ), and Having Spiritual Quotient (SQ). Whereas Syafi'i Antonio summarized into two criteria: Having professional quality and quality.

In Islam, man is the most perfect creation of Allah SWT. With the perfection given by God to man, then man has the power or potential that if developed will become Insani Resources (hereinafter called IR) that has a certain quality. And with that perfection, human is able to carry out his function as khalifah on earth. The aspect of professional quality and moral quality tend not sustainable and balanced due to have no balance in Iman (faith) and knowledge. Because the level of dignity will not be obtained if no faith and knowledge. With regard to economic activity, the aspect of faith and science as a catalyst of professional quality and moral quality leads to the function of man as khaliffah fil ard.

To support the development of sharia financial institutions, IR is needed is those who have competence in modern financial management problems and also understand the laws of sharia, especially about muamalah. To realize the system and order of sharia financial institutions are healthy and istiqomah in the implementation of sharia principles are required also IR capable of mastering sharia and financial techniques. Every IR in sharia financial institutions should be familiar with all Islamic finance concepts. The lack of skills and cognition IR in the field of Islamic isntitutions can lead to serious negative impacts such as the implementation of sharia banking is not optimal and can make the practice of Islamic isntitutions tainted by conventional culture.

Whereas, Qur'an has explained that in delivering the amanah must be to the capable receiver, it is a person who really expert in their field. Because putting someone according to his skills is one of the characteristics of Islamic professionalism. Here, the concept of insani (human-based sharia) is needed as a guide.

\section{Literature Study}

Islam defines human resources in several terms bāni ädam, al-basyar, an-nās, and al-insān. The term of bāni ādam means that human being are the descendant of Adam. The term of Al-Basyar means that human is categorized of biological creature. The term of $A n-N \bar{a} s$ means human that associated to social creature that cannot life alone and always need the others supports. The term of Al-Insān means as represent of Al mighty God as khalifah on earth and receives taklif and mandate for science including al-bayan, al-aql and al-tamyiz. In sort, the term of Al-Insān encourage humane to act creative and innovate in their life.

In the Qur'an has been explained how to choose and determine candidates Insani Resource (IR) based on certain criteria. This is in accordance with the word of Allah on QS. Al-Qașaṣ [28]: 26:

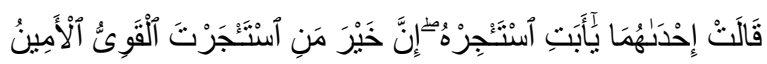

"One of the women said, "O my father, hire him. Indeed, the best one you can hire is the strong and the trustworthy." (QS. Al-Qașaṣ [28] : 26)

The statement of the verse on how to choose the IR feasibility, is also present in the word of Allah on QS. Yusuf [12]: 54-55.

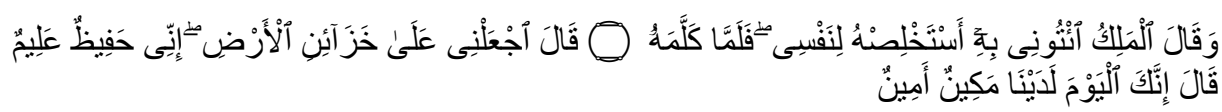

"And the king said, "Bring him to me; I will appoint him exclusively for myself." And when he spoke to him, he said, "Indeed, you are today established [in position] and trusted." 55. [Yusuf] said, "Appoint me over the storehouses of the land. Indeed, I will be a knowing guardian." (QS. Yusuf [12] : 54-55) 
Islam advocates to workers or IRs, to perform their duties and jobs without any misuse and neglect and to work efficiently. Perseverance and words in work are regarded as respectable. A small work done constantly and professionally is better than a big job done in a seasonal and unprofessional way. This is in accordance with the words of Rasulullah SAW which reads: expertise)"

"Allah loveth any one of you that if you do a job, he pursue it (earnestly and with

Competence and honesty are two traits that make a person considered a leading worker. Qur'an is asserted that competence is the most important factor in initiating one's step. In the Qur'an, it is explained about the prohibition of following what one has no knowledge of it as Allah's word on QS. Al-Isrā [17]: 36:

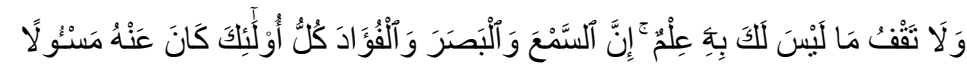

"And do not pursue that of which you have no knowledge. Indeed, the hearing, the sight and the heart - about all those [one] will be questioned." (QS. Al-Isrā [17] :36)

Rasulullah is an example for the establishment of a good character for IR, especially in the economic field. The beginning of the Prophet's gait was as a merchant, whereby he started his trade with only intangible assets. With the capital of honesty, he started his cooperation with Khadijah. Based on the first character that must be grown for IR is honesty. Competencies that are not supported with honesty will cause inequality. Then after awakening honesty and good competence, someone in addition is required to work with a team. (Fauzia \& Riyadi, 2018)

From the Encyclopedia of Islam states that the main properties possessed by the Prophet are Siddiq (true or honest), Amānah (responsibility), Fațanah (smart) and Tablig (capable). (DREI, 1999)

a. Siddiq (Honest)

Honest characters that reflect the insani resources of sharia are not only limited to say as truth, but also act according to reality. The unity between speech and action in the direction of truth is one of the characteristics of an ideal sharia insani resource.

b. Amānah (Believed)

Responsible is a further appreciation of the character of insani resources with integrity. Actions that move in accordance with commitment, business qualifications that seek every means to keep the word, and the courage to stand firm at risk for an achievement, that is the character of a responsible man. Man who has sharia character is an insan who dare to take full responsibility.

c. Fatanah (Smart)

A sharia human resource is required to be an intelligent human being. Intelligent character in question is intelligence in accordance with the field of ability that is involved.

d. Tablig (Capable)

A qualified insani resource is someone who has the ability at the level of ability to do the job well.

In Islam Rasulullah is a recognized character excellence, and the Messenger of Allah is also an example of the Insan kamil character. Based on that, the human resources should have imitated the nature of the Prophet Muhammad, as contained in the word of Allah on QS. Al-Aḥzāb [33]: 21:

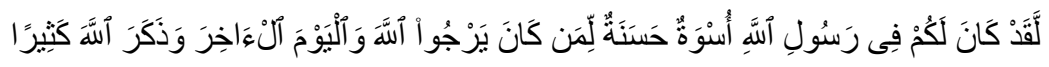


"There has certainly been for you in the Messenger of Allah an excellent pattern for anyone whose hope is in Allah and the Last Day and [who] remembers Allah often." (QS. Al-Ahzāb [33] : 21)

The above verse is a verse that explains the necessity of every human being to imitate the Messenger of Allah in various words, deeds and behavior.

The issue of Sharia-based human resources is a basic development of the theory of Islamic economic system. Islamic values that are considered universal since the beginning of the development of Islamic teachings to date, it can be implemented into spirit al-insaniyyah (humanistic). The form of the ideal Islamic sharia resources according to Islamic economics is similar to the teachings of Islam that urges followers to imitate the nature of Prophet Muhammad SAW. (Rasyid, 2014)

Insan kamil is a perfect man, in Islam Rasulullah is a human who has reached the degree of insan kamil because all the qualities are praised in the Prophet. (Figure 1)

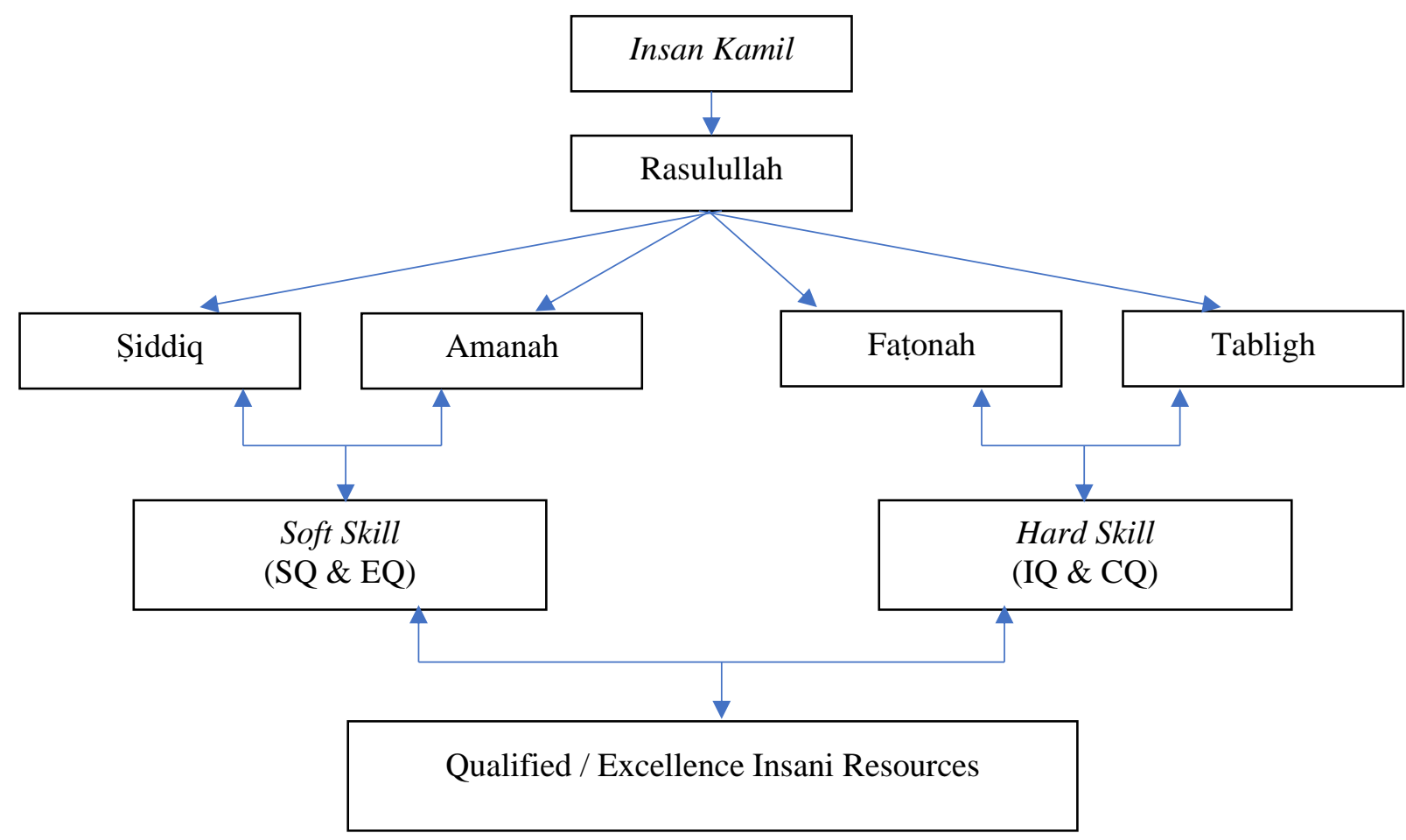

Figure 1 Insan Kamil Ways

\section{Research Methodology}

The method used in this study is library research, the research conducted by using document literature, either in the form of books, notes, or research reports from previous researchers.

In this study, researchers put the focus of research on the criteria of Insani Resources contained in the QS. Al-Qașaș [28]: 26 and QS. Yūsuf [12]: 54-55.

\section{Result And Discussion Insani Resource Criteria: Theologycal- Operational Insani Resource Criteria: Al-Qawiy Al-Amīn}

In accordance with the criteria contained in the QS. Al-Qașaș [28]: 26 which mentions the criteria of IR as Al-Qawiy Al-Amīn, the authors describe it as follows:

First, Al-Qawiy's criterion means strong, according to the author based on some references, can be interpreted the ability of IR in achieving the goal. Psychologically, the ability (ability) IR consists of potential ability (IQ) and the ability of reality 
(education). Therefore, the employee needs to be placed on the job in accordance with his expertise. Strong here can also be interpreted the power, ie power to a field.

The criteria of IR Al-Qawiy are strong include the physical strength ${ }^{1}$ and mental strength $\left(\right.$ emotional $^{2}$, intellectual ${ }^{3}$, spiritual ${ }^{4}$ ). Physical strength is the ability necessary to perform tasks that demand stamina, dexterity and strength and other characteristics. While mental strength that includes emotional, intellectual, and spiritual abilities is the necessary ability to perform various mental activities, such as thinking, reasoning and solving problems.

The right mental attitude also has an important role in everything we do, including in matters relating to the economy. Mental ability plays a bigger role in complicated work, whereas physical ability has significance for performing less demanding tasks, such as jobs whose success requires stamina, dexterity, and otherwise. Strength or ability in relation to work is a situation in an IR that is full of sincerity, efficient and successful to carry out the work to produce something optimal.

Moenir (1983) in his Humanitarian \& Organization Approach to Personnel Development said that in the ability there are 3 elements, these are the element of skill, physical elements and mental elements. These three elements are mutually supportive and the harmonious mix of the three produces something to match the requirements. Suppose a person will do something but the element of skill is not owned then even if physically and mentally he can work, then the work will not be completed. Conversely, if a person has his or her skills and physiology, it is possible but not done sincerely and mentally, the work may not be completed properly. Regarding skills, it can be explained that it is closely related to the quality of work.

One of the things that is needed by humans to achieve a goal with good results is strength. Although not enough if only by relying on strength alone. But the nature of Qawiy itself is an absolute thing that must be owned by each IRs. So, IR Qawiy is IR that has the ability to do something with agile and deft and has a lot of knowledge, able to apply everything well in accordance with the field of ability and can produce something of quality.

The second criteria is $A l-A m i n$ (trusted). The meaning of Al-Amin here refers to personal integrity that demands the nature of trust. IR Al-Amin means that IR is capable of undergoing and not abusing the beliefs it holds for its own sake. IR AlAmin should be able to fulfill the amanah given to him well. Characteristics of a professional IE must have the nature of trust, the IR is trusted and responsible. IR is a professional IRworking in accordance with the field of expertise and profession.

The character of IR Al-Amin is not only limited to say the truth, but also acts according to reality. Unity between speech and action and fully responsible for what has been done. Responsibility can mean to reflect a willingness to bear all the

\footnotetext{
${ }^{1}$ In addition to the state of health and level of physical strength, it is important in physical ability is good or poor biological function of certain parts of the body, for example between HR one very sharp eyesight and hearing, while HR others lacking in either of these two things . (Gondokusumo, 1983)

${ }^{2}$ Emotion is a condition of the organism or the individual at a certain time characterized by effective gradation from the weak level to the deep level, such as not too disappointed and very disappointed. Emotional strength can be interpreted as a person's ability to overcome emotions and can direct the positive direction. (Jahja, 2013)

${ }^{3}$ Individuals will be called intelligent if it can think abstractly and good, if less able to think abstractly, the individual concerned is less good intellect. There are seven dimensions that form the intellectual ability, these are (1) the ability to count quickly and precisely, (2) the ability to understand what is read and heard and connect words to one another, (3) the ability of similarity and visual difference quickly and precisely , (4) the ability to recognize a logical sequence in a problem and then solve the problem, (5) the ability to use logic and assess the implications of an argument, (6) the ability to imagine how an object would appear if its position in space is altered (7) retaining and recalling past experiences. (Rivai, 2012b)

${ }^{4}$ Spiritual power is one of the highest abilities, spiritual power is the non-material and soul dimension. A person who has a good spiritual ability will be able to cope with problems with well and patience. (Jahja, 2013)
} 
risks resulting from actions. Responsibility is a very good trait for human beings. ${ }^{5}$ Any matter relating to the problem of duties and responsibilities or rights and obligations of the principle of amanah which became its basic value.

Qardawi (2004) said that Muslims are obliged to improve the quality of education and training system and to prepare qualified human resources in all fields of life. Next, placing personal on the right job and in accordance with the expertise of each, so it can develop the potential optimally.

Based on this, it is appropriate whenever and wherever IR to always behave and act professionally. By actually giving a business only to the right person. In accordance with the term "the right man, in the right place and in the right time" the right person, for the appropriate position (with expertise) and in the right moment as well. This term is in accordance with the meaning of Al-Qawiy Al-Amin, if an IR meets the criteria of the nature of Al-Qawiy Al-Amin, it will bring profits and succeed in carrying out a job.

The strong and trustworthy IR (Al-Qawiy Al-Amin) is an IR with the power of which he is able to carry out the work given to him, with the amanah he fulfills in accordance with his duties and responsibilities. With trust he will put things in his place. By force he is able to fulfill his duty. The effectiveness of job implementation is the foundation for success in achieving organizational goals.

So the criteria of IR Al-Qawiy Al-Amin is IR that has the power or ability (skill) in various fields according to the digelutinya, both the physical and mental strength and the strength of the nature of amanah which they use to solve jobs that are indeed handed over and entrusted to him.

In terms of economics, Qawiy's criteria must be strong in the field of Islamic economics. He must master all forms of muamalah. IR in sharia financial institutions, are required to have expertise (Qawiy) in the field of Islamic economics. Successful development of sharia financial institution is determined by the quality of IR in it. Competence in the field of Islamic economics is the absolute thing that must be owned by IR in Islamic financial institution. Qawiy IR is the criteria that IR should have in Islamic financial institutions. Qawiy's IR criteria are IR criteria that are capable of applying syariah values because they are able to master sharia and technical banking. With mental strength (emotional, intellectual and spiritual) he will be able to overcome all forms of economic problems.

In addition to Qawiy's criteria, the Amin criterion is also an absolute must for the IR, because the Amin (trustworthy) criterion will create harmonization in all life's activities, including in the economy. An Islamic economic theorist named M. N. Siddiqi takes the mandate as the most important principle of the enactment of the Islamic Bank system, he also said "deposits will also be accepted as loans paid on demand, as a trust that can be cashed at any time (Rahardjo, 2002).

Insani Resource Criteria: Makīnun Amīnun

Based on previous explanation of Makīnun Amīnun (QS. Yusuf [12] : 54), according to the authors in accordance with the research context, the authors describe it as follows:

The first, criteria of Makinun, a high-ranking IR (strong due to position) is an IR who holds high positions in an organization (government, private or otherwise) in the place where he works. Makin IR also can be said as a strong IR, because he has a high authority power, the power is seen from the side of his position, with the position he has the power to determine and manage all what will be planned and will be done within the organization.

\footnotetext{
${ }^{5}$ Narrowly responsibility is vested in trust someone else to do. The term in Islamic responsibility is an amanah. Broadly defined responsibility as a human effort to do the mandate carefully, thoroughly, think of the good and bad, profit and loss and all things related to the act transparently causing people to believe and believe so that the deed gets a good reward or praise from others. (Abdullah, 2006)
} 
According to the authors that the criteria of IR Makin (strong because of position) can not be considered feasible if he lacks competence that is ability and skill (IR criterion Qawiy: strong or criteria IR 'Alìm: knowledgeable). The criteria of IR Makin which can be said worthy according to the author if the power or position is owned by the expertise called the power of expertise.

The power of expertise is the power gained on the basis of expertise that is formed by the ability to perform a job based on individual knowledge, information, or expertise. This power is primarily concerned with the concept of leadership which shows that the leader's ability is due to his ability better than others. Commands or other communications are accepted by others because of their assurance of their ability.

Power is the ability to influence others to achieve something in the desired way. Power is closely related to authority, but these two concepts are different. Power involves force and coercion, authority is part of a narrower scope of power. Authority is a formal power possessed by a person because of the position held in an organization. Authority is the right to do something or to order others to do or not to do something to achieve goals. The wise use of authority is a critical factor for organizational effectiveness.

Talking about the criteria of Makinun IR that is IR having high position or position if termed in Indonesian a person like this is called as "leader". While in Arabic it is called khalifah. Regarding the leader of Prophet Muhammad SAW said:

"You are all leaders and be held accountable, the government must be responsible for its people. The husband is the leader of his family and is responsible for the family he leads. The wife is the household leader of her husband and children, she is obliged to take responsibility for them. A servant is the keeper of his master's property, he is responsible for the guarded property. Remember, you are all leaders and will be responsible for that leadership." (Muttafaq Alaih)

Each IR in an organization has a certain position as the person or employee responsible for completing a field or part of the work in the organization. So the position is not solely as a leader but can be in charge of a field of work that is not classified leadership.

Secondly, the criteria of Aminun, IR that can be trusted and responsible. Amanah which is a further appreciation of the character of IR with integrity. Actions that move in accordance with commitment, business qualifications that seek all means to keep the word, and courage to stand firmly face the risks that are made for the achievement. IR $A m \bar{i} n$ is an IR who can indeed trust and be responsible in resolving all affairs or duties properly and in accordance with the goals to be achieved. In this chapter the authors do not really describe how IR $A m \overline{i n}$ criteria as already discussed in the previous discussion.

IR Makinun Aminnun is an IR (leader) who has the power, has the power or ability and is trusted to manage and run the activities for the achievement of organizational goals with effective and efficient. Every leader in a job will be held responsible for himself and the people he leads.

The author concludes that the criteria of Makinun Aminun IR, that is: has the power or position where he works both institutional government, in private institutions or companies including sharia institutions, have the competence (ability or skill) with what will be the duty and responsibility and have the nature of trust is to do with sincerity of the heart and not abuse the power and authority it has.

\section{Insani Resource Criteria: Hafīzun 'Alīmun}

Based on the above explanation about the content of QS. Yūsuf [12]: 55, then according to the authors who fit the research context, the authors describe it as follows:

First, the criteria Hafizun is to maintain or preserve. According to the author based on some references that the author understands, that Hafizun IR as well as amanah IR which refers to the integrity of a person. Hafizun IR is a person who can 
maintain a trust which has been entrusted to him, fulfill, execute and be fully responsible for the mandate given to him. So Hafizun IR is IR which always keep trust.

According to Al-Ghazali, as cited by Rivai (2012a) said that the main purpose of the Shari'a is to preserve the human welfare that includes the protection of their faith (aqidah), life, mind, descendants and their possessions. Everything that guarantees the protection of these five things is a blessing for humanity and the will of man.

Secondly, 'Alìmun is knowledgeable criterion, 'Alìmun IR in English is known as knowledge worker which means knowledgeable worker. 'Alimmun IR is a highly knowledgeable and high-knowledge IR that is needed to handle a kind of work that can make a real good contribution. Knowledge is the state of knowing, knowledge means all that is known.

Based on this, we can understand that science and knowledge is very important for IR in work, because with science an IR can work in a professional and can achieve the goal with optimal expectations. This IR is said as 'Alimmun IR. In Islamic economics IR in Islamic financial institutions not only have knowledge in the field of economics and finance, but also all forms of transactions in muamalah and know how the ethics that should be applied in the shariah financial institutions.

The characteristics of Alimun/knowledge IR are:

1. Have high proactivity. Knowledgeable IRs have a sense of responsibility and take the initiative to accomplish their tasks in accordance with their beliefs. A high sense of responsibility that led him to find alternatives to complete his work.

2. Have a willingness and high learning ability. Knowledgeable IRs have a sense of responsibility for the development of his ability and work encourages him to always learn in various opportunities.

3. Have an abundance mentality. Knowledgeable IRs have a humility that always shares their knowledge and believes that their knowledge will not diminish because of the sharing of knowledge with others, others will not share knowledge with it.

4. Have the ability to synergize. Knowledgeable IRs hav the ability to realize creative cooperation based on the ability to appreciate differences. Knowledgeable IRs realize that the best results will be achieved if they are able to synergize their knowledge and ability with others.

So Hafizun 'Alimun IR is an IR that has the ability to maintain the trust and has a high intellectual intelligence that can be relied upon to achieve the goals of the organization. In an organization such as a sharia financial institution, all IR should meet the criteria of Hafizun 'Alimun. Because if the practitioners of sharia financial institutions do not meet the criteria of Hafizun 'will make all customers no longer want to transact or use banking services, and if IR sharia financial institutions do not have criteria 'Alimmun about syariah financial institutions, it will lead to implementation of sharia in the banking becomes not optimal and no difference with the existing HR conventional. So, should IR in sharia financial institutions must meet the criteria of Hafizun 'Alimmun in accordance with the part of his position.

But in reality there are still many IRs in sharia banks that are still less knowledgeable in the field of Islamic economics. This is because the IR in Islamic financial institutions are mostly graduates of conventional or non-syariah study programs. Even sometimes choose and determine the candidate IR because of the askriptif factors. As a person concerned there is still a family relationship or factors other than ignoring the factors of competence (skills and abilities) ${ }^{6}$.

Regarding matters relating to economic activities that become the reference for the success of IR in managing its business. For example when wanting to determine an IR for sharia banking is needed not only intelligence, but also their honesty. Competence without integrity destroys a business, while integrity without competence

\footnotetext{
${ }^{6}$ In Q, S. An-Nisā "[4]: 58 it is said that: Indeed, Allah commands you to render trusts to whom they are due. In addition, there is also in the hadith of the Prophet which means: "If a business is handed over to not the experts, then wait for its destruction (HR Bukhari \& Ahmad).
} 
will hinder the progress of the business. So between competence and integrity must be balanced.

For Islamic financial institutions, the criterion of Hafizun which is preferred over 'Alimun, because Hafizun \} IR will always hold the nature of his trust, a man who can keep his knowledge and will be motivated to gain knowledge which he does not yet have, while Alimun IR may use his ability to betray his trust.

Qawiy (strong) IR is an IR that has two abilities namely physical ability and mental ability (emotional ability, intellectual ability, and spiritual ability), Makin and Alìm (high and knowledgeable) IR can also be said as Qawiy IR but criteria Makin and Alìm lead to leadership criteria. Alìm IR can also be said as Qawiy IR. Alìm IR is the same as Makīn IR. Thus Qawiy, Makin and Alìm IR lead to reliability of reliable IR (proffesionalism). While Amin IR and Hafiz IR have the same meaning that refers to the integrity of the unity between words and deeds (honest and can hold the trust and responsible).

However, if professionalism and trust can not be obtained simultaneously in a person. If this is the case, then the most useful person in the appropriate position. For example, what is needed is the war leadership, the strong criteria required in this case. But, if a position requires more trust, people who have a mandate take precedence. For the problem of syariah banking that IR still has minimal skill in syariah banking (especially muamalah field) hence in this case which is preferred is the nature of amanah, because amanah will encourage someone to be professional to its field.

The character that should be owned by each IR is a character possessed by the Messenger of Allah that is trustworthiness, IR really responsible with trust. IR is able to maintain confidence by keeping something secret that it must be kept secret, able to convey something that is supposed to be delivered.

Man with all the potential given by Allah will be able to perform functions as khalifah on earth properly. Man created and made as khalīfah aims to manage everything on earth as best as possible to achieve prosperity. To achieve results that match the goal, then it is necessary also qualified IR. The role of IR in having a very important meaning to achieve the desired goals. IR as one of the determinants of the organization's success. With the ability of an IR, the goal can be achieved optimally. IR plays an important role in the progress of Islamic Economy both in terms of quality and quantity. Shariah institutions, especially financial institutions, sharia are quite different institutions, because they should involve qualified persons who are not only experts in economics and finance, but they must have qualifications in sharia economic too.

Fauzia and Riyadi (2014) in their book entitled The Basic Principles of Islamic Economics: Maqāșid Al-Shariah Perspective says that In a company, financial institution or other activities related to economy, credibility and professionalism if the organization has three devices, namely: Insani Device (humanware), Hardware, Software.

Insani devices are individuals among institutions, from owners, directors, managers, to workers at the bottom. The human device of an institution must be adequate from quantity and harmonious in quality and praiseworthy in personality. Hardware is a means of production and the completeness of physical work that becomes a vehicle and facilities and infrastructure of the work or activities in an institution. While the software includes non-physical or virtual things such as division of work fields, decision-making procedures, authority and responsibilities of officials or workers, customer service processes, systems that organize and establish work mechanisms between sections, including software in matters related to computerial work.

In an institution, such as sharia banking, competence and integrity (criteria of $A l$ Qawiy Al-Amin, Makinun Aminun and Hafizun Alimun) are the reference for the success of IR in managing its business. For example, if you want to determine an IR that you want to put in a certain field that is needed not only intelligence, but also their 
honesty. Competence without integrity destroys a business, while integrity without competence will hinder the progress of the business. So between competence and integrity must be balanced.

If classified the criteria of Al-Qawiy Al-Amin, Makinun Aminun, and Hafizun Alimmun IR with the four characteristics of the Prophet SAFT (Șiddiq, Amānah, Fațanah and Tablig) can be described as follows:

1. Șiddiq (honest) and Amānah (trusted) / Amīn (trustworthy) and Hafiz (guard)

Siddiq (internal) is true in the word, Amānah (external) is true in words and deeds. Siddiq and Amānah are the traits of a person Amīn and Hafiz. The Amīn IR criteria is an IR criterion that has a character of an honest nature that reflects it as an IR that not only speaks according to the truth but also acts according to reality. The similarity between speech and action. Unity between speech and action. While Hafiz IR is similar to Amin IR which equally refers to integrity (is amanah). The responsibility is a further appreciation of the character of IR integrity with actions that seek all means to keep the word with deeds. The IR criteria of sharia character is an honest and trustworthy and responsible IR.

2. Fațanah (smart) and Tablīg (proficient) / Qawiy (strong), Makīn (high-ranking) and Alìm (knowledgeable)

An IR is required to be an intelligent person. Intelligent character in question is intelligence in accordance with the field of ability that is involved. Proficient is someone who has the ability at the level of ability to do the job well. This skilled character is a continuation of the intelligent character. Every insan is required not only to know, but also to apply the knowledge well.

The lack of skills and knowledge of IR in institutions that operating in the field of sharia such as sharia banking can cause negative impacts such as the implementation of Islamic sharia becomes not optimal. IR that meets the criteria of Al-Qawiy Al-Amin, Makinun Aminun and Hafizun Alimmun can be regarded as a key element in the practice of Islamic economic development. Sharia institutions are a way for qualified IR to develop Islamic economic system.

Developing IR in sharia banking is indispensable, because the success of shariah bank development is determined by the quality of management and the level of knowledge and skill of bank managers. IR in sharia banking requires not only extensive knowledge in banking but also understanding how to implement the principles of sharia in banking practices and have a strong commitment to apply consistently. In addition to requiring an in-depth understanding of sharia values and implementation in the form of real practice, it also requires strategic steps in shaping the values of sharia. In this case the IR fulfilling the criteria of Al-Qawiy Al-Amīn, Makinun Aminun and Hafizun "Alimun which is also in line with the four characteristics of the SAFT Prophet has entered the standard of qualification IR in Islamic Economic. According to the authors qualifications IR in Islamic Economics, these are:

1. Qawiy, Makin, and 'Alìm IR

a. Have expertise and skill.

b. Knowing the concept and purpose of Islamic economics, namely the attainment of falāh.

c. Knowing the concept of muamalah and can apply in Islamic economic practices such as practices in Islamic banking or other Sharia Financial Institutions.

2. Amin and Hafiz IR

a. In the context of worship is an amanah to worship God.

b. In the context of muamalah that is becoming khalifah of Allah, such as:

1) Honest.

2) Trustworthy.

3) Transparent.

4) Responsible. 
The criteria of Al-Qawiy Al-Amīn, Makīnun Amìnun and Hafìzun 'Alìmun is what every economic actor must have, this character will survive and be able to face the increasingly competitive business competition in the globalisai era. Therefore, the competence and integrity in the self must be balanced.

\section{Conclusion}

Insani in relation to Human Resources based on the Islamic theological aspect has the criteria of Al-Qawiy Al-Amīn, Makinun Amīnun and Hafižn 'Alīmun.

The criteria of IR Al-Qawiy Al-Amīn in the QS. Al-Qaș as [28]: 26 ie strong and trusted, strong (Al-Qawiy) in question includes physical strength and mental strength. Physical strength can be seen from the physical ability, while the mental strength includes emotional, intellectual and spiritual abilities. Al-Amīn is a criterion of the nature of trust that is not feared betrayed.

IR criteria Makīnun Amīnun in QS. Yūsuf [12]: 54 is a high-ranking, trustworthy, high- ranking one (Makinun) in the sense that a person has a high position (strong because of position), while Aminun is similar to the meaning of Al-Amin contained in QS. Al-Qașas [28]: 26. This verse is more directed towards leadership criteria.

Criteria IR Hafizun 'Alìmun in QS. Yūsuf [12]: 55 that is able to nurture knowledgeable, can nourish (Hafizun) is meant to maintain a mandate (amanah), so the criteria of Hafizun as well as the criteria of Al-Amīn / Amīnun. While Alīmun is knowledgeable in the sense of having knowledge or knowledge with what he maintains and with what has become his duty and responsibility.

Relevance of Al-Qawiy Al-Amīn, Makinnun Amīnun and Hafizun Alìmun in the Islamic economic context that the criteria of IR Al-Qawiy Al-Amīn, Makinun Aminun and Hafizun Alimun have entered the standard of IR qualification of Islamic economics capable of surviving and able to face business competition.

\section{References}

Abdullah, M.Y. (2006). Introduction to the Study of Ethics. Jakarta: Raja Grafindo Persada.

Ardana, I. K, et.al. (2012). Human Resource Management. Yogyakarta: Graha Ilmu.

Dewan Redaksi Ensiklopedi Islam. (1999). Islamic Encyclopedia. Jakarta: Ichtiar Baru van Houeve.

Fauzia, I. K., \& Riyadi, A. K. (2014). Basic Principles of Islamic Economics the Maqāshid Al-Syarī'ah. Jakarta: Kencana Prenada Media Group.

Gondokusumo, A. A.. (1983). Assignment Communication. Jakarta : Gunung Agung.

Jahja, Y. (2013). Developmental Psychology. Jakarta: Kencana Prenada Media Group.

Moenir, A. S. (1983). Human \& Organizational Approach Toward Staffing. Jakarta: PT Gunung Agung,

Qardawi, Y. (2004). Islam Religion of Civilization. Surakarta: Era Intermedia.

Rahardjo, M. D. (2012). Ensiklopedi Al-Qur"an: Social Interpretation Based on Key Concepts. Jakarta: Paramadina.

Rasyid, E. F. (2014). Human Resource Recruitment in Islamic Banking (Fit and Proper Test Analysis for Employee Recruitment at Bank Syariah Mandiri, Palangka Raya Branch). Palangka Raya. 
Rivai, V. (2012a). Islamic Business And Economic Ethics, Cet I. Jakarta: Bumi Aksara.

Rivai, V. (2012b). Organizational Leadership and Behavior. Jakarta : Rajawali Pers.

http://www.tafsirweb.com 